\title{
TOWARDS A POLITICAL ECONOMY OF HUMAN RIGHTS VIOLATIONS IN POST- NEW ORDER INDONESIA
}

\author{
ANDREW ROSSER \\ Indo-Pacific Governance Research Centre, University of Adelaide, Adelaide, South Australia, \\ Australia
}

Email: andrew.rosser@adelaide.edu.au

\begin{abstract}
This article reviews the literature on human rights violations in Indonesia during the post-New Order period, evaluates the explanations it provides, and suggests avenues for future inquiry drawing on insights from Richard Robison's Indonesia: The Rise of Capital and his subsequent book with Vedi Hadiz, Reorganizing Power in Indonesia: The Politics of Markets in an Age of Oligarchy. It is argued that this literature either gives insufficient attention to the nature of the Indonesian state or does so in a way that obscures the interests of the country's powerful politico-business oligarchy. Future research thus needs to examine the role of these factors, taking into account the way in which the oligarchy's interests vis-à-vis human rights are mediated by the type of right and the structure of the economy.
\end{abstract}

KEY WORDS: Human rights, Indonesia, oligarchy, political economy, Robison

More than a decade after an economic crisis that precipitated severe civil and political unrest and the collapse of the authoritarian "New Order" regime, Indonesia is now being widely touted as one of Asia's “rising powers" (Wesley 2011; Islam 2011). The Indonesian economy is growing steadily at around $6 \%$ per annum and, based on current trends, is expected to become one of the world's ten largest economies by 2050 (PriceWaterhouseCoopers 2011). The country is on track to meet many of the United Nations' Millennium Development Goals, particularly those related to the proportion of people living on less than US\$1 per day, the proportion of children under five years of age who are underweight, universal primary school enrolment and completion, gender equity in education, literacy, child mortality and the incidence of tuberculosis and malaria (Government of Indonesia 2010; UNESCAP, Asian Development Bank and UNDP 2011).These are all indicators that some of the benefits of this economic growth have filtered through to the poor. It has successfully undergone a process of democratic transition and consolidation since the end of the New Order and is now widely regarded as having one of Asia's most vibrant democracies, even if 
there has been backtracking in some areas recently (Aspinall 2010; Mietzner 2009; 2010). ${ }^{1}$ Finally, as Chair of the Association of Southeast Asian Nations (ASEAN) and a member of the Group of 20, it is also playing a more prominent role on the regional and global stages.

Despite this general picture of progress, however, the country continues to face significant problems in relation to at least one key area of development - human rights. The country's transition to democracy led to fundamental changes to the country's 1945 Constitution and legislation that served to strengthen legal protection of human rights; the most significant change was the incorporation into the Constitution of a Bill of Rights based on the Universal Declaration of Human Rights (Lindsey 2008). It also led to the establishment of a national human rights commission (Komnas HAM) empowered to study, research, disseminate, monitor, mediate and hold pre-trial inquiries into human rights issues; the creation of new human rights courts with jurisdiction over gross violations of human rights; and the introduction of new government programs aimed at promoting the realisation of poor people's rights of access to basic education and health services (Herbert 2008, 461, 466; Eldridge 2002a; Crouch 2010, 62-75; Rosser and Joshi forthcoming; Rosser 2012). Nevertheless, there have been continual serious breaches of both civil and political rights and socio-economic rights in Indonesia since the collapse of the New Order.

As Freedom House (2012) has noted, civil and political rights - such as those related to freedom of expression, assembly and religion and participation in the country's democratic political system (the rights to vote, stand for election and join political parties and organisations) - are generally upheld in Indonesia. However, the introduction of restrictive criminal defamation laws and practices has undermined citizens' rights to freely express themselves; the fact that the military and police have continued to carry out extrajudicial killings and other forms of illegal violence, particularly in conflict areas such as Maluku and Papua, has threatened citizens' rights to life, liberty and personal security. Discrimination against ethnic, religious and sexual minorities has also threatened citizens' rights to life, liberty and personal security as well as their rights to freedom of 
religion and assembly (Human Rights Watch 2010; Amnesty International 2009a; 2009b; Freedom House 2012).

At the same, many citizens have continued to experience difficulty in realising their socioeconomic rights. For instance, many citizens have been unable to access basic education and health services without paying legal and illegal fees and incurring other costs (such as for transport), with the result that some have been forced to go without such services in breach of their Constitutional rights to free basic education and free health care (the latter applying only to the poor) (Rosser and Joshi forthcoming; Rosser 2012). Similarly, more than half of the population currently lacks sustainable access to an improved water source despite the fact that the amended 1945 Constitution implicitly provides for a right to water and the 2004 Water Services Law recognizes a right to water services (Government of Indonesia 2010; Al-Afghani 2006). Finally, many poor people have suffered minimum wage violations, unfair dismissals and seizures of subsistence farming land by well-connected companies, infringing their Constitutional rights to, among other things, work, fair treatment in the workplace and the fulfilment of basic needs (Tjandra 2010; Bakker 2011).

Why has Indonesia continued to experience severe human rights violations despite the broader political and economic progress the country has made since the end of the New Order? Much of the literature on human rights in post-New Order Indonesia - and, in particular, that produced by international human rights NGOs such as Amnesty International and Human Rights Watch and organisations such as Freedom House - has focused on documenting human rights abuses rather than explaining them, reflecting these organisations' primary concern to raise awareness and mobilise public opinion against rights violations rather than provide rigorous academic analysis of their causes. At the same time, given the dramatic political, economic and legal changes that have occurred in Indonesia since the fall of the New Order, scholars of Indonesian politics and law have had plenty of other important topics to write about in recent years including the late 1990s economic crisis, democratisation, decentralisation, corruption and judicial reform. Thus, they have given relatively little attention to the causes of human rights violations. 
Nevertheless, at least four distinct perspectives on the causes of human rights violations in post-New Order Indonesia have emerged in the literature. The purpose of this article is to review and critique these perspectives and suggest avenues for future inquiry in relation to this topic drawing on insights from Richard Robison's (1986) Indonesia: The Rise of Capital (hereafter, Rise of Capital) and his subsequent book with Vedi Hadiz, Reorganizing Power in Indonesia: The Politics of Markets in an Age of Oligarchy (Robison and Hadiz 2004, hereafter, Reorganizing Power). While neither the Rise of Capital nor Reorganizing Power deal directly with issues of human rights, they are relevant to understanding the causes of human rights violations in post-New Order Indonesia to the extent that they provide a powerful explanation of state action and inaction in that country. It is widely accepted in the comparative literature on human rights that human rights violations reflect state action and inaction: indeed, this notion is embedded in international human rights law (Coomaraswamy 1997, 1256-1257; Mitchell and McCormick 1988). International human rights law requires that governments refrain from committing human rights violations themselves and, increasingly, endeavour to prevent and respond to human rights abuses committed by non-state actors. As such, they can potentially be held accountable for both their actions and inactions (Coomaraswamy 1996).

Yet, as we will see, scholars and activists writing about human rights violations in post-New Order Indonesia have not generally given much attention to the nature of the Indonesian state or have done so in a misleading or incomplete way. Specifically, they have failed to draw on perhaps the key insight of the Rise of Capital and Reorganizing Power: that state action and inaction in Indonesia has been heavily influenced by the interests of the politico-bureaucrats who occupy the state apparatus and the dominant fractions of domestic capital, forces that over recent decades have increasingly fused to form a powerful politico-business oligarchy. By tracing the rise of major domestic business groups in Indonesia since independence, their close links to senior political and bureaucratic figures and their influence over key economic policy decisions, the Rise of Capital demonstrated that Indonesian society was becoming increasingly capitalist in nature and that the 
dominant fractions of domestic capital were exercising increasing influence over the Indonesian state. At the same time, it also showed that the politico-bureaucrats were a powerful force in their own right, reflecting their occupation of the state apparatus and control over access to state facilities, licenses and resources. In Reorganizing Power, Robison and Hadiz (2004) extended this analysis to illustrate how these two groups had spawned the emergence of a powerful politicobusiness oligarchy as the sons, daughters and other relatives of senior politico-bureaucratic figures became increasingly involved in business, fusing the politico-bureaucratic and corporate worlds, and how this oligarchy survived the transition to democracy. They also pointed to the effective exclusion from political power of other social groups including labour, the peasantry and their

middle class allies in the NGO movement. By giving little attention to these ideas, the literature on human rights violations in Indonesia has missed out on the understanding that a good political economy analysis can bring, specifically one informed by the tradition in political economy represented by the Rise of Capital and Reorganizing Power.

In presenting this argument, I review each of the four main perspectives, in turn, that scholars and activists have offered so far on the causes of human rights violations in post-New Order Indonesia. I then conclude by outlining some ideas about how scholars and activists can draw on the insights of the Rise of Capital and Reorganizing Power in their future work to enhance our understanding of this topic.

\section{THE LEGALISTIC PERSPECTIVE}

Much analysis of human rights issues in post-New Order Indonesia has attributed human rights violations to inadequacies in the country's legal framework for human rights and/or the design and operation of state institutions responsible for enforcing this framework. Indonesian law, it is argued, has continued to provide poor protection of human rights and even to infringe upon them in a range of areas, notwithstanding the Constitutional and legislative changes mentioned 
above. The case of criminal defamation laws and their effect on freedom of expression is perhaps the most widely cited example in this respect (Human Rights Watch 2010). At the same time, where the law has provided adequate protection of human rights, it has generally been poorly enforced because military and police officials have failed to take action against perpetrators of human rights abuses (and indeed they have been key perpetrators of human rights abuses themselves), the Attorney-General's office and judicial system have acted corruptly and inefficiently, or the key official human rights watchdog, Komnas HAM, and the human rights courts have lacked the authority to intervene effectively (Juwana 2003; Herbert 2008). It is suggested that combined together, these factors have created a situation where state officials have been able to breach human rights with impunity, giving them little reason to respect, let alone actively protect or enforce, human rights. In policy terms, this analysis has suggested that the key to overcoming human rights violations in Indonesia is to thus implement changes in the country's human rights laws and improvements in the design and capacity of law enforcement institutions.

This perspective has figured most prominently in reports by international human rights NGOs, at least to the extent that these have gone beyond merely documenting human rights abuses. In its report on criminal defamation law and freedom of expression, for instance, Human Rights Watch $(2010,3)$ has argued that the country's criminal defamation laws have had a "continuing negative impact" on freedom of expression, implying that the laws themselves have been the primary cause of this impact. While it notes that criminal defamation complaints have often been “filed by powerful national or local actors to silence individuals who had made allegations of corruption, fraud or misconduct" (Human Rights Watch 2010, 15), it focuses overwhelmingly on the nature of the country's laws and the way they have been implemented rather than the structures of power and interests that have informed both. Similarly, the International Trade Union Confederation (2009) has pointed to legal restrictions on union and workers' rights and the Indonesian government's failure to effectively enforce the country's labour laws as the key causes of violations of trade union and workers' rights. 
This perspective has also featured in the work of legal scholars such as Juwana (2003) and Herbert (2008). To be sure, both of these scholars consider the role of political and social factors in shaping the nature of the country's legal framework for human rights and its implementation. Juwana (2003), for instance, argues that the government's human rights policies since the fall of the New Order have been heavily influenced by post-New Order presidents' respective levels of commitment to and belief in human rights. Similarly, Herbert $(2008,456)$ notes that, according to some commentators, the country's new human rights framework "has been weighed down from the outset- if not sabotaged - by vested interests keen to evade culpability for a disturbing backlog of gross violations committed under their command or by their associates." However, in explaining Indonesia's human rights problems, they nevertheless focus overwhelmingly on the content of the country's legal framework for human rights, problems in its enforcement and the incentive problems these create for state officials, implying that these factors are a much more important determinant of human rights violations than political and social factors.

By downplaying the role of political and social factors, the legalistic perspective only presents a partial understanding of the causes of human rights violations in post-New Order Indonesia. While the nature of the country's legal framework for human rights, the way it is enforced, and the incentives these create for state officials are undoubtedly important determinants of human rights violations, they are all shaped by political and social processes. The international human rights NGOs, Juwana and Herbert all acknowledge this point one way or another but, nevertheless, give analytical primacy to legal factors reflecting their legal training and focus. To fully understand the causes of human rights violations in post-New Order Indonesia, we therefore need to supplement the legalistic perspective with detailed analysis of the way in which the country's legal framework for human rights and its enforcement are shaped by political and social factors. In particular, given the crucial role of the state in determining the nature of government legislation and its implementation, we need to understand the nature of the Indonesian state. 


\section{THE CULTURALIST PERSPECTIVE}

A second perspective on the causes of human rights violations in post-New Order Indonesia has emerged out of comparative work on the relationship between culture and human rights. As Cowan and colleagues $(2001,4)$ have explained, this work has been "animated by a fundamental tension between, on the one hand, the desire to establish universal rights and, on the other hand, the awareness of cultural differences, which seems to negate the possibility of finding common ground on which to base such rights." Cultures in developing countries, it is argued, tend to stratify individuals "in ways that enhance dignity for some categories of people but leave other categories dishonoured, without dignity or respect" rather than see them as equals with a common set of rights. Indeed, these cultures may not subscribe to the notion of human rights at all (Howard 1992, 81). According to this perspective, Indonesia is thus seen as having experienced problems with human rights violations, not simply because of weaknesses in its legal framework for human rights and its implementation, but also because Indonesian cultural values, particularly as defined by state elites, are antithetical to the protection of human rights. In policy terms, this perspective thus forces a choice between the cultural relativist option of denying the legitimacy of human rights activism on the grounds that it constitutes cultural imperialism or the universalist option of promoting cultural change in developing countries so as to create a more conducive environment for human rights (Cowan et al. 2001, 4).

Arguments about cultural obstacles to human rights in Indonesia were prominent during the New Order period and, in particular, the so-called "Asian Values" debate of the 1980s and 1990s. President Suharto and other senior members of his government argued consistently that Western notions of human rights were inconsistent with the fundamental principle of the Indonesian state, namely that the state is a "family, organically united in love, and governed by a father-head who best understands the needs of its members" (Reid 1998, 25). This family principle, it was held, implied, among other things, that decisions should be made on the basis of consensus rather than 
open debate and majority voting, that group interests should be prioritized over the needs of individuals, and, accordingly, that liberal democratic forms of government that emphasised a separation of powers and individual rights should be abandoned in favour of authoritarian rule and functional group representation (Reid 1998: 25; Robison 1996). At the same time, some NGO critics of the New Order also pointed to the nature of Indonesian cultural values as an obstacle to human rights, reflecting the influence of cultural relativism within mainstream social science during this period (see, for instance, Harrison and Huntington 2000). In an account of human rights law and practice that otherwise contradicted much of the New Order's arguments about human rights, the prominent human rights activist T. Mulya Lubis $(1993,297)$, for instance, argued that three Indonesian cultural principles served to undermine human rights protection: a long-held belief in social hierarchy, a cultural obsession with maintaining harmony, and an emphasis on the importance of duties over rights. ${ }^{2}$

During the post-New Order period, the culturalist perspective has fallen out of favour, reflecting Indonesia's shift from authoritarian to democratic rule and the declining influence of cultural relativism in mainstream social science. Nevertheless, it has featured in a number of scholars' and activists' analyses of human rights violations during this period. For instance, Amnesty International $(2008,8)$ argued in its 2008 briefing to the United Nations Commission Against Torture that the continued use of torture by Indonesia's security forces reflected "a 'culture' of violence" not just within the security forces but society at large. The organisation also used culturalist arguments in its 2006 report on reproductive health issues, arguing that many health problems for Indonesian women have emanated from "specific views about gender roles and the importance of childbearing" and the relationship between sex and marriage $(2006,10)$. Finally, Eldridge (2002b) has argued that the realization of human rights in post-Suharto Indonesia has been constrained by the continuing influence of the New Order's interpretation of Pancasila, the state ideology, an interpretation based on the same values as those mentioned by Reid (1998). 
In a recent paper on human rights abuses associated with Indonesia's Criminal Code, Fitzpatrick $(2008,512)$ has criticised culturalist arguments for providing a weak explanation of human rights violations in post-New Order Indonesia. Culture, he concludes, "is of marginal relevance" to understanding these violations for two reasons. First, there are few common cultural principles that all Indonesians share and, to the extent that some do exist, these tend to be embedded in regional cultures rather than a pan-Indonesian one. It thus makes sense to view such principles as ideological constructs reflective of particular interests rather than as purely cultural phenomena. Second, most human rights violations "occur in people-state relations or an inter-cultural context" while "customary forms of authority have been significantly eroded by urbanization, transmigration, and government-sponsored development" (Fitzpatrick 2008, 512). In other words, human rights violations tend to occur, not because of conflicts over ideas and values, but factors such as access to land, wage rates, state-controlled resources, and access to public services, as well as control of the state apparatus.

This critique points to another key weakness of the culturalist perspective: its implied understanding of the nature of the Indonesian state. Scholars and activists writing from a culturalist perspective recognise that the state plays a crucial role, via its actions and inactions, in determining whose rights are upheld and whose are not. But in focusing on cultural factors, they imply that its actions and inactions are determined largely by the dominant cultural values. This is problematic, as Fitzpatrick $(2008,511-512)$ has pointed out, because we cannot understand the nature of the country's dominant values in the first place without reference to underlying material factors, in particular the interests of the ruling politico-business oligarchy. It is only by examining the oligarchic character of the post-New Order state that we can understand why some cultural principles within regional origins are privileged over others in the formulation of an official national culture and an official interpretation of the state ideology and the and the way in which these in turn constrain the state's ability to mediate struggles over land, wages rates, and so on without breaching human rights. 


\section{THE RADICAL POPULIST PERSPECTIVE}

A third perspective on the causes of human rights violations in post-New Order Indonesia has emerged out of the radical populist tradition in Indonesian political and economic thinking. As Hadiz $(1997,114)$ has noted, this tradition has been strongly concerned with issues of social justice and closely associated with analyses of Indonesia's political economy inspired by dependency theory. Accordingly, scholars and activists working within this tradition have blamed human rights violations in the post-New Order period on the state's pursuit of a "neo-colonial" model of development that has prioritised the interests of foreign multinational corporations (MNCs) and their domestic business partners over those of small and medium-sized enterprises, the middle classes and the rural and urban poor. In particular, it is argued, this model has undermined citizens' socio-economic rights by reinforcing foreign economic domination and national dependence on foreign debt and, in so doing, reducing the government's ability to fund public services and provide economic opportunities for the poor. At the same time, it has undermined citizens' civil and political rights to the extent that the Indonesian security forces have sought to facilitate foreign investment by violently suppressing local communities, labour activists and NGO activists. International financial institutions (IFIs) such as the International Monetary Fund (IMF) and World Bank have loomed large in these analyses because of their role in promoting economic policy reforms that have deepened Indonesia's integration into the international economic system and financing infrastructure projects that have displaced local communities, often without adequate compensation (ELSAM 1995; Baswir et al. 2003).In policy terms, this perspective has generated recommendations that Indonesia pursue alternative development models such as one associated with the notion of a "people's economy," the key element of which is a central role in the economy for cooperatives (see Swasono 2003 on the "people's economy”). 
Baswir and colleagues' (2003) study of the IMF's role in Indonesia following the onset of the 1997-98 economic crisis provides perhaps the clearest exemplar of this type of analysis. In an earlier book, Baswir and others (1999) presented a critique of the New Order's performance vis- $a$ vis socio-economic rights, arguing that any progress it had made in realising these rights during its 30 or so years in power had been undone by the effects of the economic crisis. The subsequent book argued that the IMF rescue packages negotiated with Indonesian government between 1997 and 2003 further undermined the realisation of socio-economic rights in Indonesia in two ways: (i) by making the economic crisis worse than it needed to be and, in so doing, robbing many poor people of the livelihood opportunities required to fulfil their rights to work, health and education; and (ii) by promoting a set of neoliberal economic policy reforms that promoted foreign economic domination and reduced the government's ability to provide economic opportunities to the poor. To make more progress in realising citizens' socio-economic rights, they recommended that the state pursue instead the "people's economy" model of development.

In contrast to legalistic and cultural relativist perspectives, the radical populist perspective gives much greater attention to the role of political and social factors in shaping human rights violations in Indonesia - indeed, these factors are at the centre of the analysis. At the same time, it also gives significant attention to the role of the state, notwithstanding the focus in Baswir and colleagues (2003) on a non-state actor. However, by understanding things in terms of neo-colonial economic structures, it presents a misleading account of the role of the state. The point here is twofold. First, as numerous studies of Indonesia's political economy have illustrated, the Indonesian state is not the mere instrument of MNCs and the IFIs, as this perspective implies. While these actors have exercised significant influence over the state, this has fluctuated considerably over time, being much greater at times of severe economic crisis when the state has needed to attract new (private) sources of investment capital than during normal times (Robison 1986; Winters 1996; Rosser 2002). To the extent that the state has had an instrumental dimension, it has been powerful politico-business families that have exercised direct control over the state reflecting their direct 
occupation of the state apparatus and fusing of political and corporate power (Robison and Hadiz 2004; Hadiz 2010; Winters 2011). Second, for reasons that I will discuss in detail below, it seems reasonable to assume that these families have had significant interests at stake in relation to human rights issues and thus an incentive as well as the means to influence state action and inaction in relation to these issues.

\section{THE BOURDIEUIAN PERSPECTIVE}

A final perspective on human rights violations in post-New Order Indonesia has emerged out of work carried out by scholars at Leiden's Van Vollenhoven Institute on "access to justice”and "legal empowerment" in developing countries (van de Meene and van Rooij 2008). This work has focused largely on trying to understand the obstacles that poor people face in defending or enforcing their rights through the justice system, distinguishing between obstacles that relate to the "demand" for justice and those that relate to its "supply." It suggests that, on the demand side, the key obstacles are "”problems related to the justice-seeker him/herself" such as "lack of experience in dealing with formal justice institutions" and "limited legal awareness and knowledge of the law and their rights" while, on the supply side, they include an excessive number of laws, use of formal legal language that is alien and inaccessible to poor people, a lack of judicial independence and costly and inefficient court processes (van de Meene and van Rooij 2008, 10-11). Underlying the latter, according to scholars working in this vein, are unequal power relationships between wealthy elites and the poor and the way in which these shape the development of the legal system. As such, this work suggests that human rights violations in developing countries stem - at least to the extent that an inability to successfully defend or enforce rights through the justice system can encourage breaches of rights in the first place - from poor people's personal incapacities and the structural context in which they operate. 
This perspective has been applied to the context of post-New Order Indonesia by Berenschot and colleagues (2011) and Vel (2010). These scholars suggest three points. Firstly, Indonesian society is divided into "haves" and "have nots" where the former is defined by their greater access to "capital" than the latter (understood in terms of Bourdieu's "species of capital" rather than, as in Marxist analysis, ownership of the means of production). Secondly, the "haves" have had a much stronger say in the formulation of Indonesian laws than the "have nots" with the result that "the legal system has acquired a subtle bias against the interests and idea of fairness towards relatively powerless sections of society" (Berenschot and Bedner 2011, 20). Finally, powerless sections of Indonesian society have had limited ability to use the court system or other formal mechanisms of justice to defend and enforce their rights when they have been violated because court cases are easily influenced by non-legal factors such as corruption and political pressure. In broad terms, these arguments are very similar to those advanced by activists at the Indonesian Legal Aid Foundation during the New Order era as part of their articulation of a "structural" approach to legal aid (see Lubis 1986; Nasution 1994). However, they differ to the extent that these activists took a pessimistic view of the potential for pursuing social justice through individual court cases (Aspinall 2005, 104), while scholars associated with the Van Vollenhoven Institute's access to justice and legal empowerment work have a more optimistic outlook, suggesting that, notwithstanding the various obstacles mentioned above, the law can still be "an instrument for [the poor] to gain more control over their lives and to address the prevailing inequalities within society"(Berenschot and Bedner 2011, 22; see a similar view, albeit outside the Bourdieuian framework, also Susanti 2008).

Like the radical populist perspective, the Bourdieuian perspective moves beyond a concern with technical legal and cultural issues to consider the role of politics in shaping human rights violations. However, also like this perspective, it presents a problematic account of the state. The issue here is that while scholars operating from this perspective distinguish between "haves" and "have nots," differentiate between them according to the extent to which they possess Bourdieuian forms of capital, make passing reference to the existence of a "ruling class," and indicate that the 
"haves" have a greater influence over the Indonesian state than the "have nots," they do not identify which specific elements within Indonesian society constitute these groups nor what their interests and agendas are vis-a-vis human rights. Yet an analysis of which actors matter, their interests and agendas, and the way in which these shape state action and inaction is crucial if we are to fully understand human rights violations in Indonesia and the potential for positive change. In broad terms, there is much in the Bourdieuian perspective that accords with the analysis of Indonesia's political economy contained in the Rise of Capital and Reorganizing Power, in particular, its concern with power relations and the role of the state in reinforcing these relations. But its vagueness in relation to key actors, interests and agendas contrasts markedly with the precise focus in the Rise of Capital on the role of the politico-bureaucrats and the dominant fractions of domestic capital and in Reorganizing Power on the role of a powerful politico-business oligarchy.

\section{ISSUES FOR FUTURE RESEARCH}

The perspectives reviewed here have addressed an important but under-researched topic in the study of Indonesia's post-New Order development: the causes of the country's continuing problems with human rights violations. However, they have provided, at best, only a partial understanding of this topic. None of these perspectives have adequately addressed the role of the state in causing or preventing human rights violations in Indonesia because they have either given little attention to the nature of the Indonesian state or done so in a way that has obscured the interests and influence of the politico-business oligarchy. In this respect, they have failed to draw on the key insights of the Rise of Capital and Reorganizing Power concerning the nature of the Indonesian state. It would be helpful if future research on the causes of human rights violations in post-New Order Indonesia gave greater attention to these insights and, in particular, explored the nature of the interests that politico-business families have at stake in relation to human rights issues. Reorganizing Power and the work of scholars such as Winters (2011) and Hadiz (2010) provide us with a good sense of how 
these families engage with and exert influence over the state. But we lack a clear sense of where their interests lie in relation to the spectrum of issues covered by "human rights."

In his analysis of human rights violations associated with the Criminal Code, Fitzpatrick (2008, 511) concludes that the Indonesian oligarchy has been the main obstacle to realising human rights in post-New Order Indonesia. Human rights abuses, he says, have reflected the fact that “integralist ideology...combined with the post-colonial institutional propensity to oligarchy to create a patrimonial state that commanded the loyalty of its officials."State officials, he says, have become "the new ruling class: arbitrary, capricious, laws unto themselves" (Fitzpatrick 2008, 511). At the same time, as international human rights NGOs have pointed out, large corporations - including ones in which members of the oligarchy have a significant financial interest - have often been implicated in human rights abuses, particularly in isolated, conflict-prone parts of the country such as Papua (Amnesty International 2002a; 2002b). But is Indonesia's oligarchy indelibly opposed to human rights? Or are its interests vis-à-vis human rights more contingent and contradictory?

A number of scholars writing about the general relationship between capitalism and human rights have suggested that the interests of capital vis-à-vis human rights depend on the particular right at stake and the structure of the economy. For instance, Sklair $(2002,308)$ has argued that there is greater tension between capitalism and socio-economic rights than capitalism and civil and political rights: capitalists "imbued with neoliberal values and the culture-ideology of consumerism tend to accept that civil and political rights (or, more rhetorically, freedoms from state interference) need to be protected to guarantee a minimum of social order" while socio-economic rights "are more problematic" for capitalists because they imply a redistribution of wealth towards other, poorer, sections of society. Similarly, Kosack (2009) has shown that while capitalists in developing countries have typically "feared" education because it undermines comparative advantage built on cheap labour, reduces their control over compliant labour forces, and promotes out-migration (Tendler 2002), in Taiwan they supported increased access to education because it promised to generate the increased numbers of skilled workers required to grow their businesses. To understand 
the interests of Indonesia's politico-business oligarchy vis-à-vis the protection of human rights, this work suggests that we need to first understand their interests in relation to particular rights or sets of rights and how these interests are shaped by the structure of the Indonesian economy.

With respect to both these points, a key issue in the Indonesian context is thus the extent to which the country is undergoing a process of industrial upgrading. Since the end of the oil boom in the early to mid-1980s, Indonesia has pursued a model of capitalist development based largely on the exploitation of natural resources and low-skilled labour, the latter being particular important in the development of labour-intensive export-oriented manufacturing industries. In the past few years, however, so-called "creative industries" have grown rapidly in Indonesia- according to the government, they currently account for 7.3 percent of GDP and approximately $\$ 10$ billion in exports (Jakarta Globe, May 17, 2011; Jakarta Post, October 6, 2011). Official reports and media commentary suggest that representatives of these industries have about concerns about the nature of the Indonesian education system on the grounds that it is not producing graduates with the requisite intellectual and creative skills (Jakarta Post, March 17, 2008; Department of Trade 2008: 21), potentially opening up an area of common ground with local and international human rights activists around the need for an improved national education system. What impact is this having on the interests of the politico-business oligarchy in relation to human rights? Has it created a contradiction for them? Or are they sufficiently disengaged from the creative industries that they do not share their concern with education? In any case, is the development of the creative industries as marked as it seems?

Looking forward, legalistic analyses of human rights violations in Indonesia can identify for us the weaknesses in Indonesian legislation and enforcement practices that need to change in order for the country to realise human rights. But it is only by examining questions such as these that we will understand the practical potential for improvements in human rights protection and the levers that might be exploited to precipitate them. In this respect, the literature on human rights violations 
in Indonesia needs to be informed by political economy analysis and in particular one that draws on the insights of the Rise of Capital and Reorganizing Power. 


\section{REFERENCES}

Al-Afghani, M. 2006. "Constitutional Court's Review and the Future of Water Law in Indonesia."Law, Environment and Development Journal,2 (1): 1-18.

Amnesty International. 2002a. "Indonesia: Human Rights are Everyone's Business in Papua." Press Release, 26 September. Accessed 16 November 2012.

http://www.amnesty.org/en/library/info/ASA21/123/2002.

Amnesty International. 2002b. Indonesia: Impunity and Human Rights Violations in Papua. London: Amnesty International.

Amnesty International. 2008. Indonesia: Briefing to the UN Committee Against Torture. London: Amnesty International.

Amnesty International. 2009a. Indonesia: Jailed for Waving a Flag: Prisoners of Conscience in Maluku. London: Amnesty International.

Amnesty International. 2009b. Unfinished Business: Police Accountability in Indonesia. London: Amnesty International.

Aspinall, E. 2005.Opposing Suharto: Compromise, Resistance and Regime Change in Indonesia. Stanford: Stanford University Press.

Aspinall, E. 2010. “Indonesia: The Irony of Success.” Journal of Democracy 21 (2): 20-34.

Bakker, L. 2011.“Pengantar: Akses Terhadap Keadilan Atas Tanah.” In Akses Terhadap Keadilan: Perjuangan Masyarakat Miskin Dan Kurang Beruntung Untuk Menuntut Hak di Indonesia, edited by W. Berenschot, A. Bedner, E. Riyadi Laggut-Terre and D. Novrianti, 39-52. Jakarta: HuMa, Van Vollenhoven Institute, KITLV-Jakarta and Epistema Institute.

Baswir, R., Hudiyanto, R. Andriono, M. Aditya, and D. Sambodo.1999. Pembangunan Tanpa Perasaan: Evaluasi Pemenuhan Hak Ekonomi, Sosial Dan Budaya. Jakarta: ELSAM.

Baswir, R., D. Heriyanto, and R. Andriyono. 2003. Terjajah di Negeri Sendiri: IMF Dan Hak Asasi Manusia di Indonesia. Jakarta: ELSAM.

Berenschot, W., and A. Bedner. 2011. "Akses Terhadap Keadilan: Sebuah Pengantar Tentang Perjuangan Indonesia Menjadikan Hukum Bekerja Bagi Semua Orang.” In Akses Terhadap Keadilan: Perjuangan Masyarakat Miskin Dan Kurang Beruntung Untuk Menuntut Hak di Indonesia, edited by W. Berenschot, A. Bedner, E. Laggut-Terre, and D. Novrianti, 3-25. Jakarta: HuMa, Van Vollenhoven Institute, KITLV-Jakarta and Epistema Institute.

Berenschot, W., A. Bedner, E. Laggut-Terre, and D. Novrianti, eds. 2011. Akses Terhadap Keadilan: Perjuangan Masyarakat Miskin Dan Kurang Beruntung Untuk Menuntut Hak di Indonesia. Jakarta: HuMa, Van Vollenhoven Institute, KITLV-Jakarta and Epistema Institute. 
Coomaraswamy, R. 1996. Further Promotion and Encouragement of Human Rights and Fundamental Freedoms, Including the Question of the Programme and Methods of Work of the Commission Alternative Approaches and Ways and Means Within the United Nations System for Improving the Effective Enjoyment of Human Rights and Fundamental Freedoms, Report of the United Nations Special Rapporteur on Violence Against Women, Its Causes and Consequences submitted in accordance with Commission on Human Rights Resolution 1995/85, 5 February. New York: United Nations Economic and Social Council. Accessed 30 September 2012. http://www1.umn.edu/humanrts/commission/thematic52/53wom.htm.

Coomaraswamy, R. 1997. "Reinventing International Law: Women's Rights as Human Rights in the International Community." Commonwealth Law Bulletin 23 (3-4): 1249-1262.

Cowan, J., M. Dembour, and R. Wilson. 2001. "Introduction.” In Culture and Rights: Anthropological Perspectives, edited by J. Cowan, M. Dembour, and R. Wilson, 1-26. Cambridge: Cambridge University Press.

Crouch, H. 2010. Political Reform in Indonesia After Soeharto. Singapore: Institute of Southeast Asian Studies.

Davidson, J. 2009. “Dilemmas of Democratic Consolidation in Indonesia.” Pacific Review 22 (3): 293-310.

Department of Trade (2008) Pengembangan Ekonomi Kreatif Indonesia 2025: Rencana Pengembangan Ekonomi Kreatif Indonesia 2009-2015, Jakarta: Department of Trade.

Eldridge, P. 2002a. "Human Rights in Post-Suharto Indonesia." Brown Journal of World Affairs 9 (1): 127-139.

Eldridge, P. 2002b. The Politics of Human Rights in Southeast Asia. London: Routledge.

ELSAM. 1995. Atas Nama Pembanguan: Bank Dunia dan Hak Asasi Manusia di Indonesia. Jakarta: ELSAM.

Fitzpatrick, D. 2008. "Culture, Ideology and Human Rights: The Case of Indonesia's Code of Criminal Procedure.” In Indonesia: Law and Society, edited by T. Lindsey, 499-514. Sydney: The Federation Press.

Freedom House. 2012. Freedom in the World 2012.Washington DC: Freedom House.

Government of Indonesia. 2010. Report on the Achievement of the Millennium Development Goals: Indonesia 2010. Jakarta: Bappenas.

Hadiz, V. 1997. “The Populist Critique.” In The Politics of Economic Development in Indonesia: Contending Perspectives, edited by I. Chalmers and V. Hadiz, 113-117. London: Routledge.

Hadiz, V. 2010. Localising Power in Post-Authoritarian Indonesia: A Southeast Asia Perspective. Stanford: Stanford University Press.

Harrison, L., and S. Huntington, eds. 2000. Culture Matters: How Values Shape Human Progress. New York: Basic Books. 
Herbert, J. 2008. "The Legal Framework of Human Rights in Indonesia.” In Indonesia: Law and Society, edited by T. Lindsey, 456-482. Sydney: The Federation Press.

Howard, R. 1992. "Dignity, Community and Human Rights." In Human Rights in Cross-Cultural Perspectives: A Quest for Consensus, edited by A. An-Na'im, 81-102. Philadelphia: University of Philadelphia Press.

Human Rights Watch. 2010. Turning Critics into Criminals: The Human Rights Consequences of Criminal Defamation Law in Indonesia. New York: Human Rights Watch.

International Trade Union Confederation. 2009. Annual Survey of Violations of Trade Union Rights 2009. Brussels: International Trade Union Confederation. Accessed 10 October 2012. http://survey09.ituc-csi.org/.

Islam, S. 2011. "Indonesia's Rise: Implications for Asia and Europe.” European View 10:165-171.

Juwana, H. 2003. “Assessing Indonesia's Human Rights Practice in the Post-Soeharto Era: 19882003.” Singapore Journal of International and Comparative Law 7: 644-677.

Kosack, S. 2009. "Realising Education for All: Defining and Using the Political Will to Invest in Primary Education.” Comparative Education 45 (4): 495-523.

Lindsey, T. 2008. "Constitutional Reform in Indonesia: Muddling Towards Democracy." In Indonesia: Law and Society, edited by T. Lindsey, 23-47.Sydney: The Federation Press.

Lubis, T. 1986. Bantuan Hukumdan Kemiskinan Struktural. Jakarta: LP3ES.

Lubis, T. 1993. In Search of Human Rights: Legal-Political Dilemmas of Indonesia's New Order. Jakarta: Gramedia and SPES Foundation.

Mietzner, M. 2009. Military Politics, Islam and the State in Indonesia: From Turbulent Transition to Democratic Consolidation. Singapore: Institute of Southeast Asian Studies.

Mietzner, M. 2010. "Political Conflict Resolution and Democratic Consolidation in Indonesia: The Role of the Constitutional Court." Journal of East Asian Studies10 (3): 397-424.

Mitchell, N., and J. McCormick. 1988. "Economic and Political Explanations of Human Rights Violations." World Politics 40 (4): 476-498.

Nasution, A. 1994. “Defending Human Rights in Indonesia.” Journal of Democracy 5 (3):114-123.

PriceWaterhouseCoopers. 2011. The World in 2050: The Accelerating Shift of Global Economic Power: Challenges and Opportunities. London: PwC Economics. Accessed January 2012. http://www.pwc.com/en_GX/gx/world-2050/pdf/world-in-2050-jan-2011.pdf

Reid, A. 1998. "Political 'Tradition' in Indonesia: The One and the Many." Asian Studies Review 22 (1): 23-38.

Robison, R. 1986. Indonesia: The Rise of Capital. Sydney: Allen and Unwin. 
Robison, R. 1996. “The Politics of “Asian Values.” Pacific Review 9 (3): 309-327.

Robison, R., and V. Hadiz. 2004. Reorganising Power in Indonesia: The Politics of Oligarchy in an Age of Markets. London: Routledge.

Rosser, A. 2002. The Politics of Economic Liberalisation in Indonesia: State, Market and Power. Richmond: Curzon.

Rosser, A., and A. Joshi. Forthcoming. "From User Fees to Fee Free: The Politics of Realising Universal Free Basic Education in Indonesia." Journal of Development Studies.

Rosser, A. 2012. "Realising Free Health Care for the Poor in Indonesia: The Politics of Illegal Fees.” Journal of Contemporary Asia 42 (2): 255-275.

Sklair, L. 2002. Globalization: Capitalism and its Alternatives. Oxford: Oxford University Press.

Susanti, B. 2008. "The Implementation of the Rights to Health Care and Education in Indonesia." In Courting Social Justice: Judicial Enforcement of Social and Economic Rights in the Developing World, edited by V. Gauri, and D. Brinks, 224-267.Cambridge: Cambridge University Press.

Swasono, S. 2003.EksposeEkonomika: Globalisme dan Kompetensi Sarjana Ekonomi. Yogyakarta: Pusat Studi Ekonomi Pancasila, Universitas Gadjah Mada.

Tendler, J. 2002.The Fear of Education. Background Paper for Conference on Inequality and the State in Latin America and the Caribbean. Washington DC: World Bank.

Tjandra, S. 2010. "Disputing Labour Dispute Settlement: Indonesian Worker's Access to Justice." Law, Social Justice and Global Development 1: 1-26.

UNESCAP, Asian Development Bank and UNDP. 2011. Accelerating Equitable Achievement of the MDGs: Closing Gaps in health and Nutrition Outcomes. Bangkok: UNESCAP.

Van de Meene, I., and B. van Rooij. 2008. Access to Justice and Legal Empowerment: Making the Poor Central in Legal Development Cooperation. Leiden: Leiden University Press.

Vel, J.,ed. 2010. “Access to Justice in Indonesia.” Law, Social Justice and Global Development, 1: 1.

Wesley, M. 2011. There Goes the Neighbourhood: Australia and the Rise of Asia. Sydney: UNSW Press.

Winters, J. 1996. Power in Motion: Capital Mobility and the Indonesian State. Ithaca: Cornell University Press.

Winters, J. 2011. Oligarchy. Cambridge: Cambridge University Press. 


\section{NOTES}

${ }^{1}$ For a contrasting view on the question of democratic consolidation, see Davidson (2009).

${ }^{2}$ Fitzpatrick $(2008,503)$ has argued that these principles are in fact more "Java-centric than panIndonesian." 


\section{University Library}

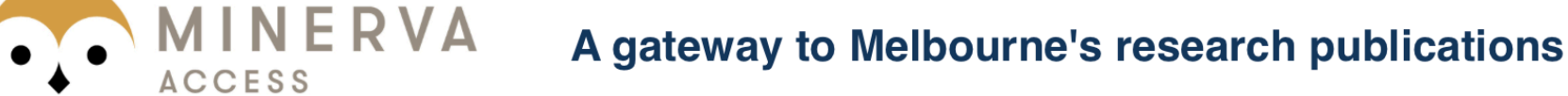

Minerva Access is the Institutional Repository of The University of Melbourne

Author/s:

Rosser, A

Title:

Towards a Political Economy of Human Rights Violations in Post-New Order Indonesia

Date:

2013-05-01

Citation:

Rosser, A. (2013). Towards a Political Economy of Human Rights Violations in Post-New Order Indonesia. JOURNAL OF CONTEMPORARY ASIA, 43 (2), pp.243-256. https:// doi.org/10.1080/00472336.2012.757436.

Persistent Link:

http://hdl.handle.net/11343/127220 